\title{
DETERMINAN HARGA SAHAM SEKTOR PROPERTI dan REAL ESTAT DI BURSA EFEK INDONESIA
}

\author{
Nuryasman dan Yessica \\ Fakultas Ekonomi Universitas Tarumanagara \\ nuryasman@fe.untar.ac.id dan handranatayessica@gmail.com
}

\begin{abstract}
This study aims to examine the effect of exchange rate (USD/IDR), inflation and BI Rate to real estate and property stock that listed in BEI from January 2010 December 2015 with 34 samples. Statistical analysis tool used was Eviews6 with the panel regression analysis and purposive sampling method. This study shows that together the USD / IDR exchange rate, inflation rate and SBI interest rate significantly influence the stock price. While partially only exchange rate USD / IDR and SBI interest rate which have significant effect to stock price.
\end{abstract}

Keywords: Stock Price, Exchange Rate, Inflation and BI Rate

\begin{abstract}
Abstrak: Tujuan penelitian ini adalah untuk menganalisis pengaruh kurs USD/IDR, tingkat inflasi dan tingkat suku bunga SBI terhadap harga saham perusahaan sektor real estate dan properti yang terdaftar di BEI dari tahun Januari 2010 - Desember 2015 dengan sampel sebanyak 34 perusahaan. Teknik analisis yang digunakan adalah analisis linear berganda dengan metode purposive sampling dari data panel dengan Eviews6. Penelitian ini menunjukan bahwa secara bersama-sama kurs USD/IDR, tingkat inflasi dan tingkat suku bunga SBI berpengaruh signifikan terhadap harga saham. Sedangkan secara parsial hanya kurs USD/IDR dan tingkat suku bunga SBI yang berpengaruh signifikan terhadap harga saham.
\end{abstract}

Kata kunci: Harga saham, Kurs, Inflasi, Suku Bunga

\section{PENDAHULUAN}

Perkembangan sektor real estate dan properti saat ini sangatlah pesat. Hal ini ditandai dengan indeks harga sektoral saham properti yang berada paling tinggi dibandingkan dengan sektor lainnya yang terdaftar di BEI, seperti terlihat pada gambar 1 berikut.

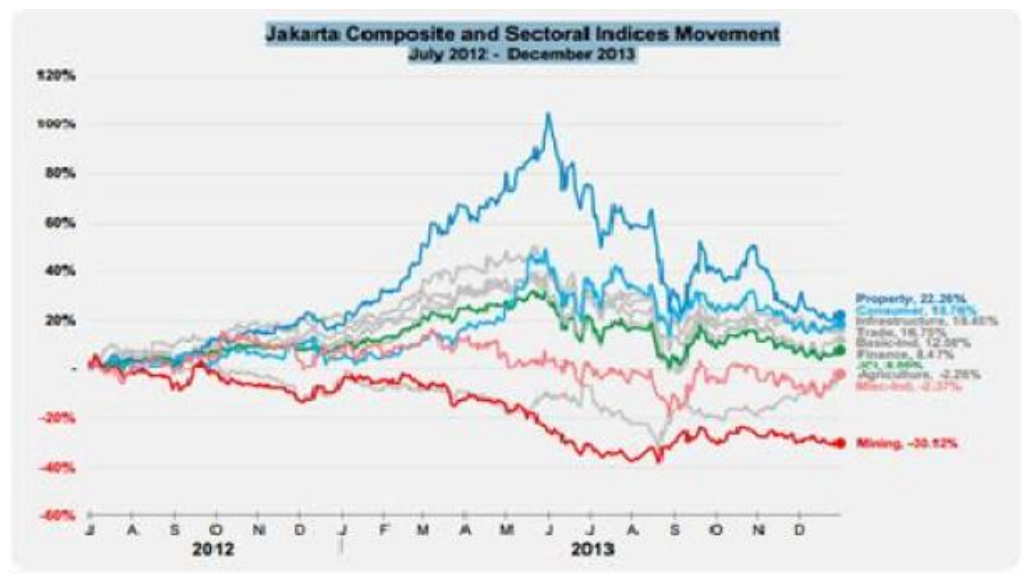

Gambar 1. Perkembangan Indek Harga Saham Sektoral di BEI Sumber : $\underline{w w w . i d x . c o . i d}$ 
Sektor properti ini kemudian menjadi salah satu sektor yang cukup penting dikarenakan volatilitasnya yang tinggi (Gambar 1) dan merupakan salah satu indikator pengukur untuk perkembangan ekonomi suatu negara. Industri properti merupakan sektor pertama yang memberi sinyal jatuh atau sedang bangunnya perekonomian suatu negara (Santoso, 2005).

Gambar 1 memperlihatkan semenjak Januari 2012 sampai Mei 2013 pergerakan indek harga saham sektor properti cenderung mengalami peningkatan yang signifikan, meskipun mulai Juni 2013 mengalami penurunan yang cukup tajam sampai mencapai puncaknya pada awal bulan September 2013 dan kembali menguat pertengahan September 2013. Meskipun indek harga saham properti sempat mengalami kontraksi yang cukup besar, tetapi masih lebih baik dibandingkan pada awal Januari 2012 dan dibandingkan sektor lainnya jauh lebih baik selama tahun 2012-2013.

Perkembangan sektor properti yang relatif naik dari tahun ke tahun membuat sektor properti menjadi pilihan investasi yang cukup menarik bagi investor. Indek Harga saham sektor properti yang lebih tinggi dibandingan dengan sektor lainnya juga didukung dengan pergerakan harga saham indeks properti yang relatif lebih tinggi dibandingkan dengan IHSG (Gambar 2)

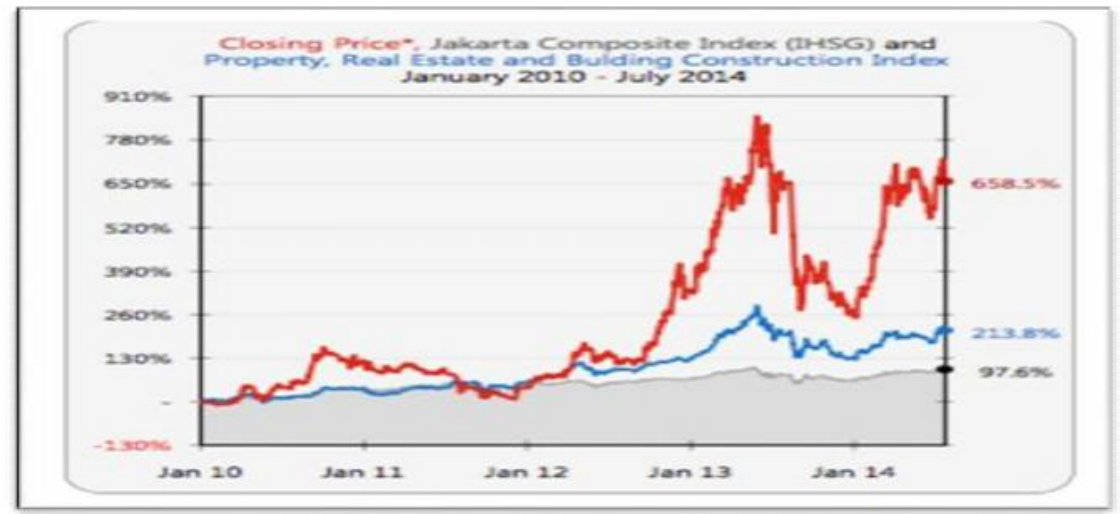

Gambar 2. Perkembangan Indek Harga Properti dan Real Estat Sumber : $\underline{w w w . i d x . c o . i d}$

Kenaikan harga saham properti ini juga didukung dengan meningkatnya volume kredit properti dalam bentuk Kredit Pemilikan Rumah (KPR) dan Kredit Pemilikan Apartemen (KPA) seperti diperlihatkan pada gambar 3 berikut.

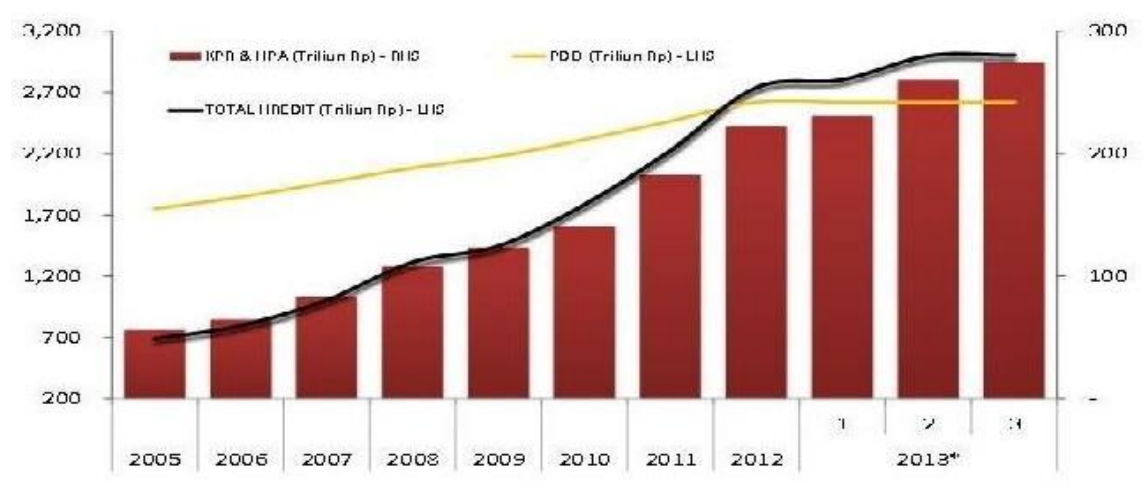

Gambar 3. Perkembangan KPR, KPA dan PDB

Sumber : www.bank indonesia.go.id 
Kepemilikan properti dalam perkembangannya lebih banyak menggunakan fasilitas kredit. Fasilitas KPR sejauh ini masih menjadi pilihan utama dalam melakukan transaksi pembelian properti dengan tingkat suku bunga pada bank persero antara 9\%-12\%. Sebagai perbandingan dapat diperhatikan gambar 4 berikut ini.

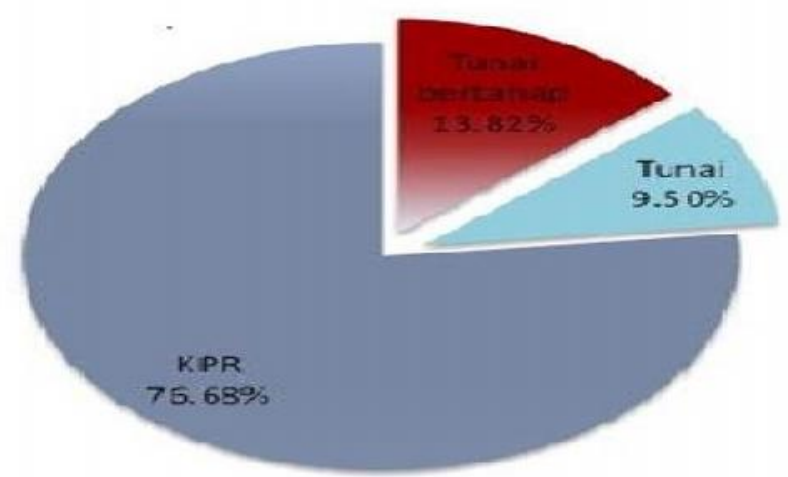

Gambar 4. Fasilitas Kepemilikan Properti dan Real Estat Sumber : www.bank indonesia.go.id

Dalam melakukan investasi di pasar modal ada beberapa hal yang harus dipertimbangkan sebelum mengambil keputusan untuk berinvestasi. Kondisi pasar modal yang pasang surut memperlihatkan bahwa kegiatan di pasar modal memiliki hubungan erat dengan kondisi ekonomi makro, karena itu kondisi ekonomi yang stabil menjadi pendorong bagi perkembangan pasar modal (Prasetiono, 2010).

Faktor-faktor yang dapat mempengaruhi keputusan dalam berinvestasi dapat berasal dari faktor internal maupun faktor eksternal perusahaan. Faktor internal seperti kondisi keuangan dan kinerja perusahaan itu sendiri. Adapun faktor eksternal perusahaan/faktor makro seperti kurs, inflasi, suku bunga memiliki dampak pada perubahan harga saham di bursa saham (Amperaningrum dan Agung, 2011).

Tingkat bunga yang terlalu tinggi akan mempegaruhi investasi dimana investasi yang ada saat ini menjadi tidak menarik lagi dan meningkatkan biaya modal yang ditanggung perusahaan. Demikian pula dengan inflasi, tingkat inflasi yang tinggi biasanya dikaitkan dengan kondisi ekonomi yang terlalu panas (Overheated). Artinya kondisi ekonomi yang mengalami permintaan atas produk yang melebihi kapasitas penawaran produknya sehingga harga-harga mengalami peningkatan. Disamping itu inflasi juga mengurangi tingkat pendapatan riil yang diperoleh investor dari investasinya. Kurs juga mempengaruhi volatilitas harga saham. Depresiasi kurs domestik akan meningkatkan ekspor yang berpengaruh pada arus kas perusahaan dan dampaknya harga saham akan naik.

Penelitian yang dilakukan oleh Rohmanda, Suhadak, dan Topowijono (2014) dengan menggunakan analisis regresi berganda untuk mengetahui apakah ada pengaruh antara variabel makro ekonomi dengan harga saham sektoral menyimpulkan bahwa bahwa kurs, inflasi dan BI Rate berpengaruh secara simultan terhadap masingmasing indeks sektoral di BEI sedangkan secara parsial kurs berpengaruh secara simultan terhadap masing-masing indeks sektoral di BEI akan tetapi untuk inflasi tidak berpengaruh secara parsial terhadap masing-masing indeks sektoral di BEI dan BI Rate hanya berpengaruh secara parsial pada harga saham di enam sektoral yang terdapat di BEI. Penelitian yang dilakukan oleh Kewal (2012) dalam jurnalnya dengan metode regresi berganda membuktikan bahwa hanya kurs yang berpegaruh secara signifikan, 
sedangkan inflasi, suku bunga SBI, dan PDB tidak berpegaruh terhadap IHSG. Salah satu penyebab dilakukan penelitian ini karena termotivasi adanya fenomena atas berbedanya hasil penelitian (Research Gap) yang dilakukan oleh beberapa penelitian terdahulu.

Penelitian ini dilakukan untuk menguji pengaruh nilai tukar USD/IDR, tingkat inflasi dan tingkat suku bunga SBI terhadap harga saham perusahaan sektor real estate dan properti yang terdaftar di BEI selama tahun Januari 2010-Desember 2015 dengan menggunakan data bulanan.

H1 : Terdapat pengaruh antara kurs USD/IDR terhadap terhadap harga saham.

$\mathbf{H}_{2}$ : Terdapat pengaruh antara tingkat inflasi terhadap harga saham.

H3 : Terdapat pengaruh antara tingkat suku bunga terhadap terhadap harga saham.

\section{KAJIAN TEORI}

Harga Saham. Harga pasar saham menurut Mulyana (2011) adalah nilai saham yang terjadi akibat diperjual belikannya saham tersebut. Sedangkan menurut Brigham dan Houston (2006) adalah harga ketika saham dijual di pasar, yang dilambangkan dengan Po.

Inflasi. Bank Indonesia (www.bi.go.id) mengartikan inflasi adalah meningkatnya hargaharga secara umum dan terus menerus. Indikator yang sering digunakan untuk mengukur inflasi adalah indeks harga konsumen (IHK).

Kurs. Menurut FASB (Financial Accounting Standard Board) nilai tukar adalah rasio antara satu unit mata uang dengan jumlah mata uang lainnya yang dapat ditukarkan pada suatu waktu tertentu.

Suku Bunga. Bank Indonesia menjelaskan suku bunga/BI Rate adalah suku bunga kebijakan yang mencerminkan sikap atau stance kebijakan moneter yang ditetapkan oleh Bank Indonesia dan diumumkan ke public (www.bi.go.id).

\section{METODE}

Dalam penelitian ini yang menjadi populasi adalah perusahaan sektor real estate dan properti yang terdaftar di Bursa Efek Indonesia Januari 2010 sampai Desember 2015. Anggota populasi yang digunakan dalam penelitian ini cukup banyak sehingga menggunakan teknik sampling untuk memudahkan dalam penelitian pemilihan sampel. Pengambilan sampel dilakukan berdasarkan metode purposive sampling, yaitu teknik pemilihan sampel perusahaan dengan tujuan untuk mendapatkan sampel selama periode penelitian berdasarkan kriteria tertentu. Beberapa kriteria yang ditetapkan untuk memperoleh sampel sebagai berikut: (1) Perusahaan sektor real estate dan properti yang telah terdaftar di Bursa Efek Indonesia selama periode penelitian yaitu tahun Januari 2010 sampai Desember 2015; (2) Perusahaan yang mempunyai data yang lengkap selama periode penelitian yaitu harga saham penutupan.

Saham dari sektor real estate dan properti saat ini yang terdaftar pada Bursa Efek Indonesia ada sebanyak 44 perusahaan. 
Teknik Analisis Data. Pertama. Regresi Panel. Menurut Ajija, dkk. (2011), ada tiga metode yang bisa digunakan untuk bekerja dengan data panel, yaitu (a) Pooling Lease Square (Common Effect). Pada model ini digabungkan data Cross Section dan data Time Series kemudian digunakan OLS terhadap data panel tersebut. Pendekatan ini merupakan pendekatan yang paling sederhana dibanding dengan kedua pendekatan lainnya. Dengan pendekatan ini tidak dapat memperlihatkan perbedaan antar individu dan perbedaan antar waktu karena Intercept maupun Slope dari model sama. Persamaan untuk Pooling Lease Square adalah sebagai berikut:

$\mathrm{Y}_{\mathrm{it}}=\alpha_{0}+\beta_{1} \mathrm{X}_{1 \mathrm{it}}+\beta_{2} \mathrm{X}_{2 \mathrm{it}}+\beta_{3} \mathrm{X}_{3 \mathrm{it}}+\ldots+\beta_{\mathrm{n}} \mathrm{X}_{\mathrm{nit}}+\varepsilon_{\mathrm{it}}$

Keterangan: $\mathrm{Y}_{\mathrm{it}}=$ variabel dependen untuk unit individu ke-i dan unit waktu ke-t; $\mathrm{X}_{\mathrm{it}}=$ variabel independen untuk unit individu ke-i dan unit waktu ke-t; $\alpha=$ intersep; $\beta=$ koefisien slope; $\varepsilon_{\mathrm{it}}=$ residual untuk unit individu ke-i dan unit waktu ke-t.

(b) Fixed Effect. Model yang mengasumsikan adanya perbedaan intersep biasa disebut dengan model regresi Fixed Effect. Model Fixed Effect dengan teknik variabel dummy dapat ditulis sebagai berikut:

$$
Y_{i t}=\sum_{i=1}^{n} \alpha_{i} D_{i}+\beta_{1} X_{1 i t}+\ldots+\beta_{n} X_{n i t}+\varepsilon_{i t}
$$

Keterangan: $Y_{i t}=$ variabel dependen untuk unit individu ke-i dan unit waktu ke-t; $X_{i t}=$ variabel independen untuk unit individu ke-i dan unit waktu ke-t; $\alpha=$ intersep; $\beta=$ koefisien slope $; \varepsilon_{\mathrm{it}}=$ residual untuk unit individu ke-i dan unit waktu ke-t; D = Dummy

(c) Random Effect. Pendekatan estimasi Random Effect ini menggunakan variabel gangguan (Error Terms). Variabel gangguan ini mungkin akan menghubungkan antar waktu dan antar perusahaan. Penulisan Random Effect dapat ditulis dengan persamaan sebagai berikut:

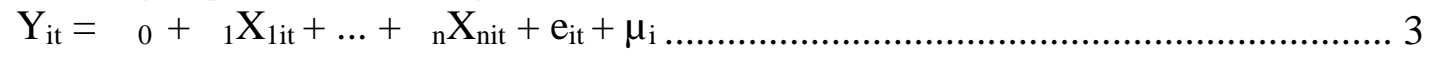

Keterangan: $\mathrm{Y}_{\mathrm{it}}=$ variabel dependen untuk unit individu ke-i dan unit waktu ke-t; $\mathrm{X}_{\mathrm{it}}=$ variabel independen untuk unit individu ke-i dan unit waktu ke-t; $\alpha=$ intersep; $\beta=$ koefisien slope $; \varepsilon_{\mathrm{it}}=$ residual untuk unit individu ke-i dan unit waktu ke-; $\mu_{\mathrm{i}}=$ random error term (error secara menyeluruh).

Untuk menentukan pendekatan regresi data panel yang akan digunakan maka dilakukan uji Hausman (Hausman Test). Hipotesis dari uji Hausman adalah sebagai berikut:

$\mathrm{H}_{0}$ : metode random effect

$\mathrm{H}_{1}$ : metode fixed effect

Apabila nilai probabilitas lebih besar dari $\alpha$ atau nilai statistik Haustman lebih kecil dari Chi-Square dengan Degree of Freedom sebesar jumlah variable bebas maka $\mathrm{H}_{0}$ tidak ditolak. Sedangkan jika nilai probabilitas lebih kecil dari $\alpha$ atau nilai statistik Haustman lebih besar dari Chi-Square dengan Degree of Freedom sebesar jumlah variable bebas maka $\mathrm{H}_{0}$ ditolak.

Pengujian Hipotesis. Kedua. Uji - t. Pengujian ini digunakan untuk mengetahui apakah terdapat pengaruh yang signifikan dari masing-masing variabel independen terhadap variabel dependen. 


\section{HASIL DAN PEMBAHASAN}

Estimasi Model Regresi Data Panel. Tahap pertama dilakukan estimasi parameter regresi data panel menggunakan pendekatan Fixed Effect dengan hasil seperti ditunjukkan tabel 2 berikut, secara statistik semua variabel bebas signifikan dalam menentukan harga saham pada sektor properti dan real estat, namun untuk interpretasi harus dipilih model regresi yang tepat dengan menggunakan uji Hausman.

Uji Hausman (Hausman Test) dilakukan untuk menentukan pendekatan regresi data panel yang akan digunakan (memilih yang terbaik antara Fixed Effect Model dengan Random Effect Model). Sebelum dilakukan uji Hausman terlebih dahulu dilakukan langkah kedua yaitu mengestimasi parameter menggunakan pendekatan Random Effect. Hasil estimasi parameter regresi menggunakan pendekatan Random Effect diperlihatkan dalam tabel 3.

Tabel 2. Pendekatan Fixed Effect Model (FEM)

Dependent Variabel : HARGA

Method : Panel Least Squares

Date : 02/04/15 Time : 23:48

Sample : 2010M01 2014M08

Periods include : 56

Cross-section include : 34

Total Panel (balanced) observations : 1904

\begin{tabular}{lcccc}
\hline \hline \multicolumn{1}{c}{ Variable } & Coefficient & Std. Error & t-Statistic & Prob. \\
\hline \hline C & -455.9010 & 222.2978 & -2.050857 & 0.0404 \\
KURS & 0.282614 & 0.023653 & 11.94823 & 0.0000 \\
INFLASI & 39.81446 & 16.04427 & 2.481538 & 0.0132 \\
RATE & -259.9366 & 43.15155 & -6.023807 & 0.0000 \\
\hline \hline \multicolumn{4}{c}{ Effect Specification } \\
\hline \hline R-squared & \multicolumn{3}{c}{ Cross-section fixed (dummy variables) } \\
Adjusted R-squared & 0.579795 & Mean dependent var & 835.7873 \\
S.E of regression & 0.571693 & S.D dependent var & 1262.190 \\
Sum square resid & 826.0427 & Akaike info criterion & 16.29041 \\
Log likelihood & $1.27 E+09$ & Schwartz criterion & 16.39830 \\
F-statistic & -15471.47 & Hannan-Quinn criterion & & 16.33012 \\
Prob (F-statistic) & 71.55755 & Durbin-Watson stat & 0.191167 \\
\hline \hline
\end{tabular}

Tabel 3. Pendekatan Random Effect Model (REM)

Dependent Variabel : HARGA

Method : Panel EGLS (Cross-section random effects)

Date : 02/16/15 Time : $16: 12$

Sample : 2010M01 2015M12

Periods include : 72

Cross-section include : 34

Total Panel (balanced) observations : 2448

Swamy and Arora estimator of component variances

\begin{tabular}{lcccc}
\hline \hline \multicolumn{1}{c}{ Variable } & Coefficient & Std. Error & t-Statistic & Prob. \\
\hline \hline C & -455.9010 & 273.7420 & -1.665441 & 0.0960 \\
KURS & 0.282614 & 0.023653 & 11.94823 & 0.0000 \\
INFLASI & 39.81446 & 16.04427 & 2.481538 & 0.0132 \\
RATE & -259.9366 & 43.15155 & -6.023807 & 0.0000 \\
\hline \hline
\end{tabular}




\begin{tabular}{llll}
\hline \hline R-squared & 0.092336 & Mean dependent var & 98.35812 \\
Adjusted R-squared & 0.090903 & S.D dependent var & 866.3579 \\
S.E of regression & 826.0427 & Sum square resid & $1.30 \mathrm{E}+09$ \\
F-statistic & 64.42862 & Durbin-Watson stat & 0.187847 \\
Prob (F-statistic) & 0.000000 & & \\
\hline \hline
\end{tabular}

Berdasarkan hasil pengujian Hausman yang diperlihatkan pada tabel 4 berikut, nilai probabilitas yang dihasilkan sebesar 0.99999 berarti lebih besar dari $\alpha$ sebesar 5\% maka $\mathrm{H}_{0}$ diterima atau model terbaik yang dapat digunakan untuk interpretasi adalah Random Effect Model (REM).

Tabel 4. Uji Hausman (Hausman Test)

Correlated Random Effects - Hausman Test

Equation : REM

Test cross-section random effects

\begin{tabular}{lccc}
\hline \hline Test Summary & Chi-Squared Statistic & Chi-Squared d.f. & Probability \\
\hline \hline Cross-section random & 0.000000 & 3 & 0.99999 \\
\hline \hline
\end{tabular}

Pengujian Hipotesis. Uji - t. Uji-t dilakukan untuk menguji koefisien regresi secara parsial yaitu untuk menguji terdapat pengaruh yang signifikan dari masing-masing variabel independen terhadap variabel dependen jika variabel independen yang lain dianggap konstan.

\section{Pengujian Hipotesis Pertama:}

1. $\mathrm{H}_{0}: \beta_{1}=0$ artinya tidak ada pengaruh yang signifikan antara variabel kurs terhadap harga saham.

$\mathrm{H}_{1}: \beta_{1} \neq 0$ artinya terdapat pengaruh yang signifikan antara variabel kurs terhadap harga saham.

2. Nilai tingkat nyata $(\alpha)$ yang digunakan sebesar $5 \%$.

3. Jika $p$-value $>5 \%$ tidak ada alasan untuk menolak hipotesis nol atau sebaliknya.

Nilai probabilitas (p-value) dari variabel kurs pada tabel 6 diperoleh sebesar 0,0000 yang lebih kecil dari 5\%, sehingga dapat dikatakan secara statistik perubahan kurs akan mempengaruhi perubahan harga saham sektor properti dan real estat yang ada di Bursa Efek Indonesia.

\section{Pengujian Hipotesis Kedua:}

1. $\mathrm{H}_{0}: \beta_{2}=0$ artinya tidak ada pengaruh yang signifikan antara variabel inflasi terhadap harga saham.

$\mathrm{H}_{1}: \beta_{2} \neq 0$ artinya terdapat pengaruh yang signifikan antara variabel inflasi terhadap harga saham.

2. Nilai tingkat nyata $(\alpha)$ yang digunakan sebesar $5 \%$.

3. Jika $p$-value $>5 \%$ tidak ada alasan untuk menolak hipotesis nol atau sebaliknya.

Hasil penelitian ini menemukan p-value untuk variabel inflasi sebesar 0,2240 yang lebih besar dari 5\%. Hal ini dapat diartikan secara statistik tidak ada alasan yang kuat untuk menolak hipotesis nol, sehingga dapat disimpulkan bahwa dalam penelitian ini variabel inflasi tidak mempengaruhi harga saham sektor properti dan real estat. 


\section{Pengujian Hipotesis Ketiga}

1. $\mathrm{H}_{0}: \beta_{3}=0$ artinya tidak ada pengaruh yang signifikan antara variabel suku bunga terhadap harga saham.

$\mathrm{H}_{1}: \beta_{3} \neq 0$ artinya terdapat pengaruh yang signifikan antara variabel suku bunga terhadap harga saham.

2. Nilai tingkat nyata $(\alpha)$ yang digunakan sebesar $5 \%$.

3. Jika $p$-value $>5 \%$ tidak ada alasan untuk menolak hipotesis nol atau sebaliknya.

Tabel 4 menunjukkan hasil probabilitas dari variabel suku bunga sebesar 0,0000. Nilai ini lebih kecil dari 5\% yang berarti cukup alasan untuk menerima hipotesis alternatif dan menolak hipotesis nol, sehingga dapat disimpulkan secara statistik perubahan suku bunga (BI Rate) sangat signifikan dalam menentukan perubahan harga saham sektor properti dan real estat pada tingkat kepercayaan $95 \%$.

Koefisien Determinasi $\mathbf{R}^{2}$. Koefisien determinasi $\left(\mathrm{R}^{2}\right)$ mengukur seberapa besar kontribusi (pengaruh) yang diberikan oleh variabel independen terhadap variabel dependen. Nilai $\mathrm{R}^{2}$ yang mendekati nol berarti variabel independennya hanya mampu menjelaskan sedikit informasi yang dibutuhkan untuk menjelaskan nilai dari variabel dependennya. Dari hasil diatas dapat dilihat bahwa koefisien determinasi yang diperoleh dari penelitian ini adalah 9.09\%. Hasil ini menunjukkan bahwa variabel independen dalam penelitian ini seperti kurs, inflasi dan suku bunga dalam model regresi dapat menjelaskan variabel dependen yaitu harga saham sektor properti dan real estat sebesar $9,09 \%$ sedangkan sisanya sebesar $90.91 \%$ dijelaskan oleh faktor-faktor lain di luar variabel-variabel independen yang digunakan dalam penelitian ini. Dari hasil Tabel 6 diatas didapatkan persamaan regresi panel dengan menggunakan metode Random Effect adalah sebagai berikut:

Harga $_{\text {it }}=395,9205+0,158092$ Kurs $_{\text {it }}+15,49298$ Inflasi $_{\text {it }}-219,2166$ Rate $_{\text {it }}$

Berdasarkan uji $\mathrm{F}$, variabel independen yaitu kurs, inflasi dan suku bunga menunjukkan hasil signifikan mempengaruhi harga saham properti pada $\alpha$ sebesar $5 \%$. Hal ini terlihat dari hasil uji $\mathrm{F}$ paling sedikit ada satu variabel independen, yaitu kurs, inflasi dan suku bunga mempengaruhi harga saham pada tingkat keyakinan 95\% dengan nilai probabilitas 0.0000 .

Dari ketiga variabel independen yaitu kurs, inflasi dan suku bunga semuanya menunjukkan pengaruh yang signifikan mempengaruhi harga saham. Penelitian ini sejalan dengan penelitian yang dilakukan Rohmanda, Suhadak, dan Topowijono (2014) serta Krisna dan Wirawati (2013) bahwa ada pengaruh antara inflasi, kurs dan suku bunga secara bersama-sama terhadap indeks harga saham IHSG di BEI. Kurs atau nilai tukar adalah salah satu alat pembayaran khususnya dollar Amerika yang paling sering digunakan dan menjadi salah satu alat transaksi yang diakui secara internasional. Naiknya atau turunnya kurs akan mempengaruhi harga saham. Hal ini juga berkaitan dengan kepemilikan investor asing atas saham-saham perusahaan yang terdaftar di Bursa Efek Indonesia.

Tingkat suku bunga merupakan kebijakan yang digunakan oleh pemerintah sebagai salah satu instrumen untuk menjaga kestabilan ekonomi di suatu negara dalam hal ini suku bunga di Indonesia diatur oleh Bank Indonesia. Penurunan suku bunga biasa dilakukan oleh Bank Sentral pada saat terjadinya resesi di suatu negara. Hal ini dikarenakan dengan suku bunga yang rendah, keinginan masyarakat untuk menabung 
juga akan menurun. Penurunan tingkat suku bunga juga akan diikuti dengan turunnya tingkat suku bunga kredit, sehingga membuat masyarakat lebih tertarik untuk melakukan pinjaman ke bank khususnya untuk modal usaha sehingga uang yang beredar di masyarakat akan bertambah dan juga diikuti dengan meningkatnya pertumbuhan perekonomian karena pinjaman modal usaha dari bank tersebut. Bank Indonesia juga akan menaikan tingkat suku bunga apabila jumlah uang yang beredar di masyarakat sudah mulai melebihi target yang ditetapkan atau terjadinya inflasi.

Kondisi tingkat inflasi akan berpengaruh pada naiknya harga barang termasuk didalamnya harga bahan pokok untuk produksi sehingga hal ini akan membebankan perusahaan khususnya dalam hal produksi dan juga akan mempengaruhi harga jualnya. Kenaikan harga suatu produk yang terlalu tinggi akan membuat penjualan menurun sehingga harga saham perusahaan tersebut juga turun.

Berdasarkan uji-t hasil menunjukkan nilai probabilitas dari kurs adalah 0.0000, berarti terdapat pengaruh signifikan kurs USD/IDR terhadap harga saham. Koefisien regresi sebesar 0.158092, artinya setiap kenaikan satu satuan kurs USD/IDR akan menaikan harga saham sebesar 0.158092 satuan. Hasil penelitian sesuai dengan penelitian yang dilakukan oleh dengan Kewal (2012), Rohmanda, Suhadak dan Topowijono (2014), Krisna dan Wirawati (2013) yang menyatakan bahwa kurs berpengaruh signifikan terhadap harga saham.

Menurut Kewal (2012) kurs mempengaruhi volatilitas harga saham. Depresiasi mata uang domestik akan meningkatkan volume ekspor. Bila permintaan pasar internasional cukup elastis, hal ini akan meningkatkan cash flow perusahaan domestik yang kemudian akan tercermin pada harga sahamnya. Sebaliknya jika emiten membeli produk dalam negeri dan memiliki hutang luar negri dalam bentuk dollar maka harga sahamnya akan turun. Namun penelitian ini bertentangan dengan penelitian yang dilakukan oleh Aperaningrum dan Agung (2011), dimana variabel kurs memiliki koefisien regresi positif, artinya apabila kurs naik maka harga saham akan naik. Hal ini terjadi khususnya pada harga saham properti dikarenakan sebagian investasi pada sektor properti berasal dari investor asing. Pada saat kurs dollar Amerika terhadap rupiah naik (rupiah melemah) dan investor asing menmberikan investasinya pada sektor properti di Indonesia maka nilainya dalam rupiah akan bertambah banyak. Tambahan investasi dari investor asing ini dapat digunakan baik untuk kelangsungan perusahaan kedepannya, ekspansi maupun diinvestasikan kembali sehingga nilai perusahaan serta pertumbuhan / growth perusahaan meningkat yang akan berpengaruh pada naiknya harga saham perusahaan tersebut.

Kenaikan kurs juga dapat menjadi satu momentum yang tepat bagi masyarakat yang selama ini berinvestasi dalam bentuk dollar. Masyarakat dapat mencairkan investasinya dalam bentuk rupiah dengan nilai yang lebih banyak dan menginvestasikannya pada sektor property. Hal ini dikarenakan sektor properti memiliki tingkat investasi yang cukup aman dan menjanjikan karena harga properti yang cenderung naik dari tahun ke tahun serta di dukung dengan naiknya harga tanah tempat properti tersebut dibangun sehingga secara langsung harga saham properti di Bursa Efek Indonesia juga naik.

Pengaruh inflasi terhadap harga saham sektor properti dalam penelitian ini secara statistik tidak signifikan dalam menentukan harga saham. Hal ini dibuktikan dengan uji-t dengan hasil menunjukkan nilai probabilitas dari inflasi adalah 0.2240. 
Besarnya pengaruh inflasi terhadap harga saham ditunjukkan oleh koefisien regresi sebesar 15.49298, artinya setiap kenaikan satu satuan inflasi akan menaikan harga saham sebesar 15.49298 satuan. Penelitian ini sesuai dengan penelitian Tobing (2009), Kewal (2012) dan Rohmanda, Suhadak, dan Topowijono (2014) yang menyatakan bahwa terdapat pengaruh signifikan antara inflasi terhadap harga saham. Namun, penelitian ini tidak sejalan dengan penelitian yang dilakukan oleh Utami dan Rahayu (2003) serta Krisna dan Wirawati (2013).

Inflasi dalam penelitian ini tidak berpengaruh secara signifikan terhadap harga saham sektor properti dikarenakan berinvestasi di sektor properti membutuhkan dana investasi yang cukup besar. Masyarakat yang tidak memiliki saving atau tabungan lebih untuk berinvestasi akan kesulitan untuk berinvestasi di sektor ini. Sedangkan inflasi berpengaruh besar pada harga-harga kebutuhan pokok khususnya bahan pangan dimana seseorang yang akan berinvestasi di sektor properti pasti sudah dapat mencukupi kebutuhan pokoknya dan kondisi ekonominya tidak terganggu dengan adanya inflasi sehingga dengan terjadinya inflasi tidak berpengaruh pada sektor properti.

Berdasarkan uji t hasil menunjukkan nilai probabilitas dari kurs adalah 0.0000, berarti terdapat pengaruh signifikan profitabilitas terhadap harga saham. Koefisien regresi sebesar 219.2166 artinya setiap kenaikan satu satuan tingkat suku bunga akan menurunkan harga saham sebesar 219.2166 satuan. Hal ini serupa dengan penelitian Utami dan Rahayu (2003), dengan hasil suku bunga signifikan dengan harga saham dan menyatakan bahwa suku bunga merupakan salah satu pertimbangan penting sebelum melakukan investasi. Jika suku bunga turun maka orang akan cenderung melakukan investasi jangka panjang tetapi apabila suku bunga naik maka orang akan cenderung menunda investasi jangka panjang. Akan tetapi penelitian ini sedikit berbeda dengan penelitian Aperaningrum dan Agung (2011) dengan hasil suku bunga signifkan tetapi dengan koefisien positif terhadap harga saham

Variabel tingkat suku bunga memiliki koefisien regresi negatif, artinya apabila suku bunga naik maka harga saham akan turun. Kenaikan suku bunga akan membuat masyarakat lebih tertarik untuk menyimpan uang nya di bank dibandingkan menginvestasikannya di pasar modal sehingga harga saham akan turun. Kenaikan suku bunga juga akan menghambat penyaluran kredit usaha sehingga akan mempengaruhi kelangsungan perusahaan-perusahaan yang ada termasuk di dalamnya sektor properti yang membutuhkan dana yang cukup besar dalam melaksanakan pembangunan proyeknya sehingga harga saham akan turun. Sebaliknya, turunya tingkat suku bunga akan mendorong masyarakat untuk menginvestasikan investasinya pada pasar modal dan tingkat suku bunga yang rendah juga akan menarik para pengusaha ataupun investor untuk melakukan pinjaman modal usaha. Dalam hal ini khususnya sektor properti yang membutuhkan dana yang cukup besar dalam menjalankan proyek pembangunan akan sangat terbantu dalam hal pinjaman modal usaha sehingga harga saham properti akan naik seiring dengan turunya tingkat suku bunga.

\section{PENUTUP}

Simpulan. Dari hasil pengujian dan analisis yang telah dilakukan mengenai pengaruh kurs, inflasi, dan suku bunga terhadap harga saham menunjukkan ketiga variabel tersebut dalam model regresi dapat menjelaskan harga saham sebesar 9,09\% sedangkan sisanya sebesar $90,91 \%$ dijelaskan oleh faktor-faktor lain di luar variabel-variabel independen 
yang digunakan dalam penelitian ini. Berdasarkan hasil analisis dapat diambil kesimpulan sebagai berikut: (1) Kurs USD/IDR, tingkat inflasi, dan tingkat suku bunga secara bersama- sama memiliki pengaruh positif dan signifikan terhadap harga saham perusahaan pada sektor real estate dan properti di Bursa Efek Indonesia periode Januari 2010 hingga Desember 2015; (2) Kurs USD/IDR secara parsial memiliki pengaruh positif dan signifikan terhadap harga saham perusahaan pada sektor real estate dan properti di Bursa Efek Indonesia; (3) Inflasi secara parsial tidak signifikan terhadap harga saham perusahaan pada sektor real estate dan properti di Bursa Efek Indonesia; (4) Suku bunga secara parsial memiliki pengaruh negatif dan signifikan terhadap harga saham perusahaan pada sektor real estate dan properti di Bursa Efek Indonesia.

Saran. Saran bagi pemerintah adalah pemerintah harus memperhatikan serta mengkontrol kondisi ekonomi yang berkaitan langsung dengan kondisi pasar modal dengan kebijakan moneternya. Hal ini dikarenakan berdasarkan penelitian yang dilakukan menyatakan bahwa kurs USD/IDR, tingkat inflasi inflasi, dan tingkat suku bunga mempengaruhi harga saham, bagi Investor sebelum melakukan transaksi di pasar modal diharapkan untuk mempertimbangkan faktor makro ekonomi yang ada, dan yang terakhir saran bagi penelitian selanjutnya adalah dapat menggunakan sampel dari perusahaan sektor lain selain sektor real estate dan properti serta variabel makro ekonomi lainnya dan menggunakan periode waktu yang lebih lama.

\section{DAFTAR RUJUKAN}

Ajija, S., R. dkk. (2011) Cara Cerdas Menguasai EVIEWS. Jakarta: Salemba Empat. Amperaningrum, I. dan Agung, R.S. (2011)" Pengaruh Tingkat Suku Bunga SBI, Nilai Tukar Mata Uang, dan Tingkat Inflasi Terhadap Perubahan Harga Sub Sektor Perbankan di Bursa Efek Indonesia Tahun 2005-2009". Jurnal Universitas Gunadarma, 4, 160-163.

Bringham, E.F dan Houston, J.F. (2006) Dasar-Dasar Manajemen Keuangan, Buku Kesatu, Edisi Kesepuluh. Jakarta: Salemba Empat.

Krisna, A., A., A.,G. dan Wirati, N.,G., P. (2013) "Pengaruh Inflasi, Nilai Tukar Rupiah, Suku Bunga SBI, Pada Indeks Harga Saham Gabungan di BEI". E-Journal Akutansi Universitas Udayana, hal. 421-435.

Kewal, S,.S. (2012) "Pengaruh Inflasi, Suku Bunga, Kurs, dan Pertumbuhan PDB Terhadap Indeks Harga Saham Gabungan”. Jurnal Economia, 8 (1), 53-64

Mulyana, Deden (2011) "Analisis Likuidtas Saham Serta Pengaruhnya Terhadap Harga Saham Pada Perusahaan yang Berada Pada Indeks LQ45 di Bursa Efek Indonesia”, Jurnal Magister Manajemen, 4 (1), 77-96

Prasetiono, D.,W. (2010) “Analisis Pengaruh Faktor Fundamental Ekonomi Makro dan Harga Minya Terhadap Saham LQ45 Dalam Jangka Pendek dan Jangka Panjang”, Journal of Indonesian Economic Applied, 4 (1), 11-25.

Rohmanda, D., Suhadak, dan Topowiyono. (2013) "Pengaruh Kurs Rupiah, Inflasi, dan BI Rate Terhadap Harga Saham (Studi Pada Indeks Sektoral Bursa Efek Indonesia Periode 2005-2013)", Jurnal Administrasi Bisnis (JAB), 13 (1), 4-9.

Santoso, B. (2005). Prospek Kredit Properti 2005, Economic Review Journal No 199. 
Tobing, R., L. (2009) Analisis Pengaruh Nilai Tukar, Inflasi, dan Suku Bunga Terhadap Pergerakan Indeks Harga Saham Gabungan di Bursa Efek Indonesia Selama Periode 2004-2008.

Utami, M. dan Rahayu, M. (2003) "Peranan Profitabilitas, Suku bunga, Inflasi, dan Nilai Tukar Dalam Mempengaruhi Pasar Modal Indonesia Selama Krisis Ekonomi", Jurnal Manajemen \& Kewirausahaan, 5 (2). 